\title{
Front Matter: Volume 7702
}

, "Front Matter: Volume 7702," Proc. SPIE 7702, Quantum Information and Computation VIII, 770201 (20 May 2010); doi: 10.1117/12.865617

SDIE Event: SPIE Defense, Security, and Sensing, 2010, Orlando, Florida, United SPIE. States 


\section{PROCEEDINGS OF SPIE}

\section{Quantum Information \\ and Computation VIII}

Eric J. Donkor

Andrew R. Pirich

Howard E. Brandt

Editors

8-9 April 2010

Orlando, Florida, United States

Sponsored and Published by

SPIE

Volume 7702 
The papers included in this volume were part of the technical conference cited on the cover and title page. Papers were selected and subject to review by the editors and conference program committee. Some conference presentations may not be available for publication. The papers published in these proceedings reflect the work and thoughts of the authors and are published herein as submitted. The publisher is not responsible for the validity of the information or for any outcomes resulting from reliance thereon.

Please use the following format to cite material from this book:

Author(s), "Title of Paper," in Quantum Information and Computation VIII, edited by Eric J. Donkor, Andrew R. Pirich, Howard E. Brandt, Proceedings of SPIE Vol. 7702 (SPIE, Bellingham, WA, 2010) Article CID Number.

ISSN 0277-786X

ISBN 9780819481665

Published by

SPIE

P.O. Box 10, Bellingham, Washington 98227-0010 USA

Telephone +1 3606763290 (Pacific Time) · Fax +1 3606471445

SPIE.org

Copyright (C) 2010, Society of Photo-Optical Instrumentation Engineers

Copying of material in this book for internal or personal use, or for the internal or personal use of specific clients, beyond the fair use provisions granted by the U.S. Copyright Law is authorized by SPIE subject to payment of copying fees. The Transactional Reporting Service base fee for this volume is $\$ 18.00$ per article (or portion thereof), which should be paid directly to the Copyright Clearance Center (CCC), 222 Rosewood Drive, Danvers, MA 01923. Payment may also be made electronically through CCC Online at copyright.com. Other copying for republication, resale, advertising or promotion, or any form of systematic or multiple reproduction of any material in this book is prohibited except with permission in writing from the publisher. The CCC fee code is 0277-786X/10/\$18.00.

Printed in the United States of America.

Publication of record for individual papers is online in the SPIE Digital Library.

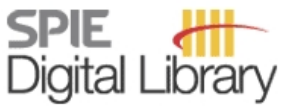

SPIEDigitalLibrary.org

Paper Numbering: Proceedings of SPIE follow an e-First publication model, with papers published first online and then in print and on CD-ROM. Papers are published as they are submitted and meet publication criteria. A unique, consistent, permanent citation identifier (CID) number is assigned to each article at the time of the first publication. Utilization of CIDs allows articles to be fully citable as soon they are published online, and connects the same identifier to all online, print, and electronic versions of the publication. SPIE uses a six-digit CID article numbering system in which:

- The first four digits correspond to the SPIE volume number.

- The last two digits indicate publication order within the volume using a Base 36 numbering system employing both numerals and letters. These two-number sets start with 00, 01, 02, 03, 04, $05,06,07,08,09,0 A, 0 B \ldots 0 Z$, followed by 10-1Z, 20-2Z, etc.

The CID number appears on each page of the manuscript. The complete citation is used on the first page, and an abbreviated version on subsequent pages. Numbers in the index correspond to the last two digits of the six-digit CID number. 


\section{Contents}

vii Conference Committee

\section{SESSION 1 QUANTUM ALGORITHM I}

770202 Quantum informational model of 3+1 dimensional gravitational dynamics [7702-01]

J. Yepez, Air Force Research Lab. (United States)

770203 Quantum algorithms for the Jones polynomial [7702-02]

L. H. Kauffman, Univ. of Illinois at Chicago (United States); S. J. Lomonaco, Jr., Univ. of Maryland, Baltimore County (United States)

770204 Observation of two-color ghost imaging [7702-23]

S. Karmakar, Y. Shih, Univ. of Maryland, Baltimore County (United States)

770205 Liffed Jacobi equation for varying penalty parameter in the Riemannian geometry of quantum computation [7702-04]

H. E. Brandt, U.S. Army Research Lab. (United States)

770206 Quantum algorithms for virtual Jones polynomials via Thistlethwaite theorems [7702-05] M. Vélez, J. Ospina, EAFIT Univ. (Colombia)

770207 Poincare recurrence and intermittent destruction of the quantum Kelvin wave cascade in quantum turbulence [7702-06]

G. Vahala, The College of William \& Mary (United States); J. Yepez, Air Force Research Lab. (United States); L. Vahala, Old Dominion Univ. (United States); M. Soe, Rogers State Univ.

(United States); S. Ziegeler, High Performance Technologies, Inc., (United States)

\section{SESSION 2 QUANTUM ALGORITHM II}

770208 Jacobi fields in the Riemannian geometry of quantum computation [7702-07]

H. E. Brandt, U.S. Army Research Lab. (United States)

770209 Quantum lattice-gas model of spinor superfluids [7702-08]

J. Yepez, Air Force Research Lab. (United States); G. Vahala, The College of William \& Mary (United States); L. Vahala, Old Dominion Univ. (United States); M. Soe, Rogers State Univ. (United States)

\section{SESSION 3 CRYPTOGRAPHY, QKD}

7702 OC Optimal individual attack on BB84 quantum key distribution using single-photon two-qubit quantum logic [7702-11]

R. García-Patrón, F. N. C. Wong, J. H. Shapiro, Massachusetts Institute of Technology (United States) 
7702 OD Comparison of quantum key distribution over fiber optics network topologies [7702-12]

E. Donkor, Univ. of Connecticut (United States)

7702 OE Experimental quantum cryptography scheme based on orthogonal states: preliminary results [7702-13]

A. Avella, G. Brida, I. P. Degiovanni, M. Genovese, M. Gramegna, P. Traina, Istituto Nazionale di Ricerca Metrologica (Italy)

7702 OF Efficient key integrity verification for quantum cryptography using combinatorial group testing [7702-14]

J. Fang, The Univ. of Hong Kong (Hong Kong, China) and South China Normal Univ. (China); Z. L. Jiang, S. M. Yiu, L. C. K. Hui, The Univ. of Hong Kong (Hong Kong, China); Z. Li, Beijing Electronic Science and Technology Institute (China)

7702 OG Pauli channels exhibit a transition effect in memory estimation above a parametric threshold [7702-15]

M. R. Frey, Bucknell Univ. (United States); L. E. Coffey, Rowan Univ. (United States);

L. K. Mentch, Bucknell Univ. (United States); A. L. Miller, Muskingum Univ. (United States);

S. S. Rubin, Williams College (United States)

\section{SESSION 4 QUANTUM ENTANGLEMENT}

$7702 \mathrm{OH} \quad$ Compensated crystal assemblies for type-Il entangled photon generation in quantum cluster states [7702-17]

M. Fanto, T. McEwen, R. Erdmann, Air Force Research Lab. (United States); E. Galvez, Colgate Univ. (United States)

7702 Ol Quantum interferometer and radar theory based on N00N, M and M or linear combinations of entangled states [7702-18]

J. F. Smith III, U.S. Naval Research Lab. (United States)

7702 OJ Four-qubit cluster state entanglement in the presence of decoherence [7702-19]

G. Gilbert, Y. S. Weinstein, MITRE Corp. (United States)

7702 OK Measurement and analysis of a coupled three-particle quantum system [7702-20]

S. E. Rodríguez Gómez, EAFIT Univ. (Colombia)

\section{SESSION 5 QUANTUM IMAGING}

7702 OM Quantum astronomy with Iqueye [7702-22]

I. Capraro, Univ. of Padua (Italy) and ADAPTICA Srl (Italy); C. Barbieri, Univ. of Padua (Italy); G. Naletto, Univ. of Padua (Italy) and CNR IFN LUXOR UOS Padua (Italy); T. Occhipinti, Univ. of Padua (Italy) and ADAPTICA Srl (Italy); E. Verroi, P. Zoccarato, S. Gradari, Univ. of Padua (Italy)

$77020 \mathrm{~N} \quad$ Factorization algorithm based on the periodicity measurement of a continuous truncated exponential sum [7702-03]

V. Tamma, Univ. of Maryland, Baltimore County (United States) and Univ. degli Studi di Bari (Italy); H. Zhang, X. He, Univ. of Maryland, Baltimore County (United States); A. Garuccio, Univ. degli Studi di Bari (Italy); Y. Shih, Univ. of Maryland, Baltimore County (United States) 
$770200 \quad$ Low-noise amplification of a continuous-variable quantum state [7702-24]

R. C. Pooser, Oak Ridge National Lab. (United States); A. M. Marino, Joint Quantum Institute, National Institute of Standards and Technology and Univ. of Maryland (United States); V. Boyer, The Univ. of Birmingham (United Kingdom); K. M. Jones, Williams College (United States); P. D. Lett, Joint Quantum Institute, National Institute of Standards and Technology and Univ. of Maryland (United States)

7702 OP Noise from the perspective of weak values [7702-25]

J. E. Gray, A. D. Parks, Naval Surface Warfare Ctr. Dahlgren (United States)

$7702 \mathrm{OQ} \quad$ Minimum single-photon detector bias for linear mode operation using Mach-Zehnder modulator interference [7702-26]

K. Colladay, Johns Hopkins Univ. (United States); B. Vorees, Univ. of Maryland, College Park (United States); B. Jacobs, Johns Hopkins Univ. (United States)

\section{SESSION 6 QUANTUM COUPLING}

7702 OR Indications for quantum computation requirements from comparative brain analysis [7702-27]

G. Bernroider, Univ. of Salzburg (Austria); W. Baer, Naval Postgraduate School (United States)

7702 OS Design and implementation of a quantum compiler [7702-28] T. S. Metodi, S. D. Gasster, The Aerospace Corp. (United States)

7702 OT A new software-based architecture for quantum computer [7702-29]

N. Wu, F. Song, Nanjing Univ. (China); X. Li, The City Univ. of New York (United States)

7702 OU High-fidelity universal quantum gates through quantum interference [7702-30] R. Li, Kent State Univ. (United States), RIKEN (Japan), and CREST, Japan Science and Technology Agency (Japan); F. Gaitan, Lab. for Physical Sciences (United States), RIKEN (Japan), and CREST, Japan Science and Technology Agency (Japan)

7702 OV Gate control of a quantum dot single-electron spin through geometric phases: Feynman disentangling method [7702-34]

S. Prabhakar, J. E. Raynolds, A. Inomata, State Univ. of New York at Albany (United States)

\section{SESSION 7 QUANTUM INFORMATION THEORY}

7702 OW Theoretical discussion for quantum computation in biological systems [7702-31]

W. Baer, Naval Postgraduate School (United States)

7702 OY Hawk-Dove-Bully-Retaliator quantum game CAS aided [7702-33]

J. M. López R., EAFIT Univ. (Colombia)

Author Index 
Downloaded From: https://www.spiedigitallibrary.org/conference-proceedings-of-spie on 26 Apr 2023

Terms of Use: https://www.spiedigitallibrary.org/terms-of-use 


\title{
Conference Committee
}

\author{
Symposium Chair
}

Michael T. Eismann, Air Force Research Laboratory (United States)

Symposium Cochair

William Jeffrey, HRL Laboratories, LLC (United States)

Conference Chairs

Eric J. Donkor, University of Connecticut (United States)

Andrew R. Pirich, ACP Consulting (United States)

Howard E. Brandt, U.S. Army Research Laboratory (United States)

Program Committee

Paul Alsing, Air Force Research Laboratory (United States)

Chip B. Elliott, BBN Technologies (United States)

Reinhard K. Erdmann, Air Force Research Laboratory (United States)

Michael J. Hayduk, Air Force Research Laboratory (United States)

Louis H. Kauffman, University of Illinois at Chicago (United States)

Vladimir E. Korepin, Stony Brook University (United States)

Samuel J. Lomonaco, Jr., University of Maryland, Baltimore County (United States)

John M. Myers, Harvard University (United States)

Vladimir Privman, Clarkson University (United States)

Alexander V. Sergienko, Boston University (United States)

Tai Tsun Wu, Harvard University (United States)

\section{Session Chairs}

1 Quantum Algorithm I

Andrew R. Pirich, ACP Consulting (United States)

Eric J. Donkor, University of Connecticut (United States)

2 Quantum Algorithm II

Michael J. Hayduk, Air Force Research Laboratory (United States)

Paul Alsing, Air Force Research Laboratory (United States)

3 Cryptography, QKD

Howard E. Brandt, U.S. Army Research Laboratory (United States)

Louis H. Kauffman, University of Illinois at Chicago (United States) 
4 Quantum Entanglement

Samuel J. Lomonaco, Jr., University of Maryland, Baltimore County (United States)

5 Quantum Imaging

Eric J. Donkor, University of Connecticut (United States)

Reinhard K. Erdmann, Air Force Research Laboratory (United States)

6 Quantum Coupling

Louis H. Kauffman, University of Illinois at Chicago (United States)

Samuel J. Lomonaco, Jr., University of Maryland, Baltimore County (United States)

7 Quantum Information Theory

Howard E. Brandt, U.S. Army Research Laboratory (United States) 